Article

\title{
Decision Support System for Selection of Candidates for PASKIBRAKA Using the TOPSIS Method
}

\author{
Nungsiyati $^{1}$, Sri Hartati ${ }^{2}$, Deli Wahana Aprilianti ${ }^{3}$ \\ 1,2,3 Information System Study Program STMIK Pringsewu Lampung \\ 1,2,3 Jalan Wisma Rini No. 09 Pringsewu, Lampung, Indonesia
}

\begin{tabular}{l}
\hline SUBMISSION TRACK \\
\hline Received : Aug 21, 2020 \\
Final Revision : Sept 22, 2020 \\
Available Online : Sept 29, 2020 \\
KEYWORD \\
\hline Criteria, PASKIBRAKA, Selection, \\
Candidates, TOPSIS Method \\
CORRESPONDENCE \\
\hline Phone: 0729-22240 \\
E-mail: nungsiyati12@ gmail.com
\end{tabular}

\section{INTRODUCTION}

Every year in every region in Indonesia a selection is held to make it easier to carry out various activities stipulated in the Regulation of the Minister of Youth and Sports NO 0065 of 2015[1]. Selection of Paskibraka members starts at the school, city / district level. Provincial and National where the weight of the assessment at each level is different, the method used by the committee is still using the manual method, which will hamper and slow down the announcement

\section{A B S T R A C T}

Activities in the selection of candidates for PASKIBRAKA every year aim to find the best sons and daughters who will be assigned as heirloom flag raisers. Selection of candidates for PASKIBRAKA members is done manually, to determine the final score of each participant. The selection committee still uses paper and is separate from the assessment to one criterion with the other criteria. In the assessment process with a large number of participants it will take a long time. To simplify the assessment process, a decision support system is needed for the selection of PASKIBRAKA candidates, using the TOPSIS Method (Technique for Order Preference by Similarity to Ideal Solution). TOPSIS is one method that is easy to use to solve multi-criteria problems by taking into account the values of existing criteria. Based on the results of the case example, the candidate PASKIBRAKA selection shows that the results of the experiment use the same system as the manual calculation. And the calculation of the TOPSIS Method will produce output in the form of ranking from PAKIBRAKA candidates process. One way to overcome this problem is the existence of a system that can provide recommendations for consideration for making decisions appropriately and quickly.

There are several articles on methods to solve this problem. As in[2]using the Fuzzy TOPSIS method in dealing with the selection problem of employee acceptance. The calculation results show the same value and are usually accepted or declared valid, this is based on the comparison of the calculation results with Ms. software. Excel and Matlab. 
On[3] using the TOPSIS method to determine scholarship recipients based on different criteria for each existing scholarship. The results show that the results of calculations using the same system as manual calculations are able to provide recommendations for scholarships. Satriawaty Mallu uses the TOPSIS Method to calculate and provide the final result of the ranked assessment so that it can determine contract employees to become permanent employees[4]. Research conducted for scholarship admissions includes the Simple Additive Weighting Method. The decision support system in determining scholarship acceptance is based on predetermined criteria by looking for the weight value for each attribute, then a ranking process is carried out which will determine the optimal alternative, namely the best student[5][6] - [8]. Rika Yunitarini (2013) uses the SMART Method (Simple multi attribute rating technique) for the selection of the best radio broadcaster. The results or output are in the form of a report or value report for the best radio broadcasters Radio Delta FM Surabaya based on predetermined criteria and sub criteria[9].

In the selection, there are criteria used for the assessment, namely parade, PBB (rowing rules), parade, psychological test, body / samapta, health and fitness, interviews, regional arts, and general knowledge. Each of these criteria has several sub-criteria that will be scored by each jury. So far, the assessment process for the selection of candidate members for Paskibraka is done manually on paper and separate assessments for one criterion with other criteria, such as on nonacademic tests.

To simplify the assessment process, a decision support system is needed for the selection of candidate members of Paskibraka by applying the TOPSIS (Technique for
Order Preference by Similarity to Ideal Solution) Method. The TOPSIS method is a method with a simple concept, easy to understand, can solve multi-criteria problems by taking into account the values of the existing criteria. The TOPSIS method is also a method that has a concept where the best chosen alternative not only has the shortest distance from the positive ideal solution, but also has the longest distance from the negative ideal solution.[10] - [12].

Based on this, this study uses the TOPSIS method for the selection of Paskibraka candidates. In order to help provide decision recommendations for the selection team for candidate members of Paskibaka.

\section{METHODS}

\subsection{Data collection}

In the process of making a decision support system for the selection of a candidate for Paskibraka, correct and accurate supporting data is needed, therefore some of the data collection techniques used in this study are as follows:

1. Observation

In this study, the research conducted observations or field surveys by observing the Paskibraka selection process.

2. Interview (Interview)

Interviews were conducted with one of the Paskibraka selection committee. In the interview process, a question and answer process was carried out regarding matters related to the process of selecting a Paskibaka candidate, such as what criteria were evaluated, then the assessment process.

3. References 
In carrying out library research, the author searches for material on notes, literature and books. This is very useful for system design guidelines and author references related to the selection of the national Paskibraka candidate.

\subsection{TOPSIS}

Technique for Order Preference by Similarity to Ideal Solution (TOPSIS) is based on the concept where the best chosen alternative not only has the shortest distance from the positive ideal solution, but also has the longest distance from the negative ideal solution Steps to solve the problem with TOPSIS [13] - [15]:

a. Create a normalized decision matrix.

b. Create a weighted normalized decision matrix.

c. Determine the ideal positive solution matrix \& negative ideal solution matrix.

d. Determine the distance between the value of each alternative with the positive ideal solution matrix \& the negative ideal solution matrix.

e. Specifies the preference value for each alternative.

TOPSIS requires a performance rating of each alternative $\mathrm{Ai}$ on each normalized $\mathrm{Cj}$ criterion, namely:

$r_{i j}=\frac{x_{i j}}{\sqrt{\sum_{-=1}^{m} x_{i j}^{2}}}$

$\mathrm{i}=1,2, \ldots . \mathrm{m}$; and $\mathrm{j}=1,2, \ldots . \mathrm{n} . \mathrm{A}+$ positive ideal solution and A- negative ideal solution can be determined based on the normalized weight rating (yij) as

$y_{r j}=w_{i j} r_{i j}$

with $\mathrm{i}=1,2, \ldots . \mathrm{m}$; and $\mathrm{j}=1,2, \ldots$..n.

$A^{+}=\left(y_{1}^{+}, y_{2}^{+}, \ldots y_{n}^{+}\right)$
$A^{-}=\left(y_{1}^{-}, y_{2}^{-}, \ldots y_{n}^{-}\right)$

With

$y_{1}^{+}$

$=\left\{\max y_{i j} ; j i k a j\right.$ adalah atribut keuntungan

$=\left\{\begin{array}{l}\min y_{i j} ; \text { jika } j \text { adalah atribut biaya } \\ \text { a }\end{array}\right.$

$y_{1}^{-}=\left\{\begin{array}{l}\min y_{i j} ; j i k a j \text { adalah atribut keuntungan } \\ \max y_{i j} ; j i k a j \text { adalah atribut biaya }\end{array}\right.$

The distance between the alternative $\mathrm{Ai}$ and the positive ideal solution is defined as:

$D_{i}^{+}=\sqrt{\sum_{i=1}^{n}\left(y_{i}^{+}-y_{i j}\right)^{2}}$

The distance between the alternative $\mathrm{Ai}$ and the negative ideal solution is defined as:

$\left.D_{i}^{-}=\sqrt{\sum_{i=1}^{n}\left(y_{i j}-y_{i}^{-}\right.}\right)^{2}$

Specifies a preference value for each alternative:

$v_{i}=\frac{D_{i}}{D_{i}^{+}+D_{i}^{+}}$

A larger Vi value indicates that the alternative $\mathrm{Ai}$ is preferred.

The criteria and weight for the selection of candidates for Paskibraka are stated in Table 1 as follows:

Table 1. Criteria and Weight Value (W)

\begin{tabular}{llc}
\hline Code & Criteria & Weight \\
\hline C1 & Parade & $15 \%$ \\
C2 & UN & $15 \%$ \\
C3 & Psychological test & $20 \%$ \\
C4 & Samapta / Physical & $15 \%$ \\
C5 & Health and fitness & $15 \%$ \\
& & \\
C6 & Interview & $5 \%$ \\
C7 & Regional Arts & $5 \%$ \\
& & \\
C8 & General knowledge & $10 \%$ \\
\hline
\end{tabular}


The following are several sets of criteria and their branches used for classification determination are stated in Table 2 to Table 8 below:

Table 2. Parade Criteria (C1)

\begin{tabular}{clcc}
\hline No. & The set & Information & Twig \\
\hline 1 & $>175$ & Very good & 5 \\
2 & $171-174$ & Well & 4 \\
3 & $166-170$ & Enough & 3 \\
4 & $161-165$ & Less & 2 \\
5 & $<160$ & Very less & 1 \\
\hline
\end{tabular}

Table 3. UN Criteria (C2)

\begin{tabular}{cccc}
\hline No. & The set & Information & Twig \\
\hline 1 & $>90$ & Very good & 5 \\
2 & $77-89$ & Well & 4 \\
3 & $64-76$ & Enough & 3 \\
4 & $51-63$ & Less & 2 \\
5 & $<50$ & Very less & 1 \\
\hline
\end{tabular}

Table 4. Psychological Criteria (C3)

\begin{tabular}{cccc}
\hline No. & The set & Information & Twig \\
\hline 1 & $>90$ & Very good & 5 \\
2 & $77-89$ & Well & 4 \\
3 & $64-76$ & Enough & 3 \\
4 & $51-63$ & Less & 2 \\
5 & $<50$ & Very less & 1 \\
\hline
\end{tabular}

Table 5. Samapta / Physical Criteria (C4)

\begin{tabular}{cccc}
\hline No. & The set & Information & Twig \\
\hline 1 & $>90$ & Very good & 5 \\
2 & $77-89$ & Well & 4 \\
3 & $64-76$ & Enough & 3 \\
4 & $51-63$ & Less & 2 \\
5 & $<50$ & Very less & 1
\end{tabular}

Table 5. Health and Wellness Criteria (C5)

\begin{tabular}{ccc}
\hline No. & Information & Twig \\
\hline 1 & Very good & 5 \\
2 & Well & 4 \\
3 & Enough & 3 \\
4 & Less & 2 \\
5 & Very less & 1 \\
\hline
\end{tabular}

Table 6. Interview Criteria (C6)

\begin{tabular}{cccc}
\hline No. & The set & Information & Twig \\
\hline 1 & $>90$ & Very good & 5 \\
2 & $77-89$ & Well & 4 \\
3 & $64-76$ & Enough & 3 \\
4 & $51-63$ & Less & 2 \\
5 & $<50$ & Very less & 1 \\
\hline
\end{tabular}

Table 7. Regional Art Criteria (C7)

\begin{tabular}{cccc}
\hline No. & The set & Information & Twig \\
\hline 1 & $>90$ & Very good & 5 \\
2 & $77-89$ & Well & 4 \\
3 & $64-76$ & Enough & 3 \\
4 & $51-63$ & Less & 2 \\
5 & $<50$ & Very less & 1 \\
\hline
\end{tabular}

Table 8. Regional Art Criteria (C8)

\begin{tabular}{cccc}
\hline No. & The set & Information & Twig \\
\hline 1 & $>90$ & Very good & 5 \\
2 & $77-89$ & Well & 4 \\
3 & $64-76$ & Enough & 3 \\
4 & $51-63$ & Less & 2 \\
5 & $<50$ & Very less & 1 \\
\hline
\end{tabular}

\subsection{Research Framework}


The stages of the process to be carried out in this study are described in Flowchat in Figure 3.1 as follows:

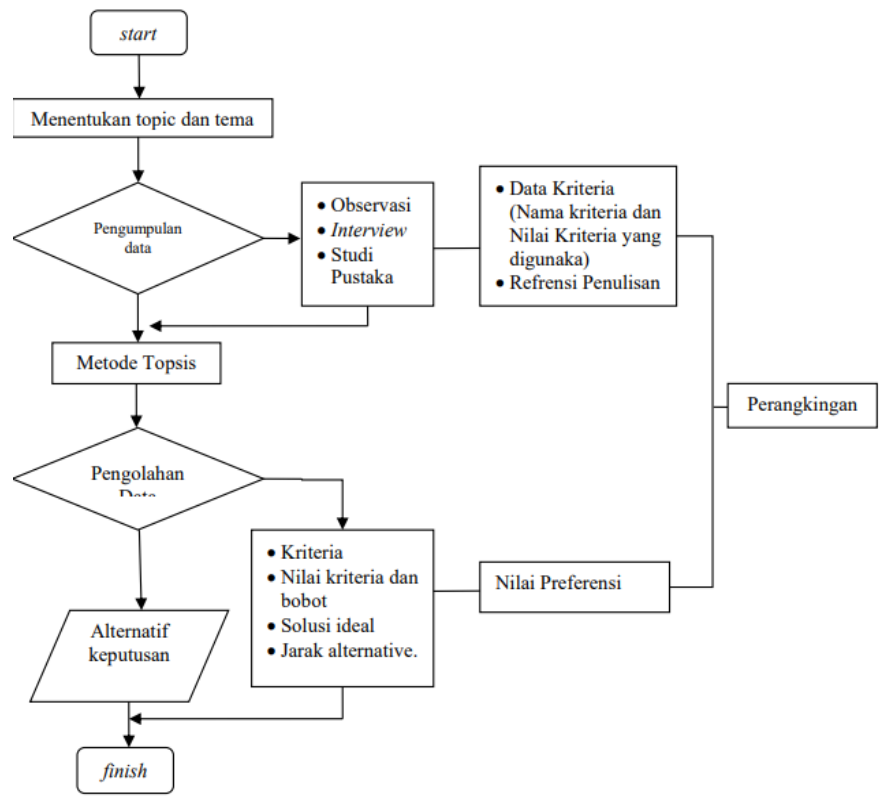

Figure 3.3. Research Diagram

Information :

1. The first stage is to determine the research title by determining the topic and theme first.

2. The second stage is data collection, the methods used by researchers are observation, interviews and library studies. In the interview process, a question and answer process was carried out regarding matters related to the Paskibaka candidate selection process, such as what criteria were evaluated, then the assessment process.

3. Stage three, the researcher uses the TOPSIS method for the decision support system.

4. Stage four is data processing. In data processing, the researcher must determine the criteria, criterion values and weights, ideal solutions, alternative distances that produce preference values.

\section{RESULT}

In this study, the alternative that will be ranked is the candidate for Paskibraka selection. based on the criteria, candidates for Paskibraka will get a selection value. The

\begin{tabular}{llc}
\hline Code & Criteria & Weight \\
\hline C1 & Parade & $15 \%$ \\
C2 & UN & $15 \%$ \\
C3 & Psychological test & $20 \%$ \\
C4 & Samapta / Physical & $15 \%$ \\
C5 & Health and fitness & $15 \%$ \\
& & \\
C6 & Interview & $5 \%$ \\
C7 & Regional Arts & $5 \%$ \\
& & \\
C8 & General knowledge & $10 \%$ \\
\hline
\end{tabular}

Table 10. Criteria and Weight Value (W) 
Each sub-criteria is assessed from a range of 1-5 which can be seen in table 3 to table 9. The value to be given to each alternative for all criteria can be seen in table 11 .

Table 11. Score Each Criterion

$\begin{array}{rrrrrrrrr}\text { Name } & \text { C1 } & \text { C2 } & \text { C3 } & \text { C4 } & \text { C5 } & \text { C6 } & \text { C7 } & \text { C8 } \\ \text { Coco } & 4 & 2 & 2 & 4 & 4 & 4 & 2 & 3 \\ \text { Rani } & 5 & 2 & 3 & 4 & 4 & 3 & 3 & 2 \\ \text { Ita } & 4 & 3 & 2 & 2 & 4 & 4 & 3 & 4 \\ \text { Hana } & 3 & 2 & 1 & 2 & 3 & 4 & 4 & 4 \\ \text { Irgi } & 2 & 5 & 2 & 2 & 3 & 1 & 1 & 3 \\ \text { Rian } & 3 & 5 & 4 & 2 & 2 & 1 & 4 & 2 \\ \text { riza } & 5 & 4 & 2 & 2 & 3 & 4 & 3 & 2\end{array}$

The assessment process for the selection of candidates for the Paskibraka:

1. To form a weighted normalized decision matrix, the calculation is determined by the Topsis standard formula using,

The formula $=r_{i j}=\frac{x_{i j}}{\sqrt{\sum_{i=1}^{m} x_{i j}^{2}}}$

$$
\begin{aligned}
& \mathrm{XI}=\sqrt{4^{2}+5^{2}+4^{2}+3^{2}+2^{2}+3^{2}+5^{2}}=10,198 \\
& \mathrm{R} 11=\frac{4}{10.198}=0.392 \\
& \mathrm{R} 21=\frac{5}{10.198}=0.490 \\
& \mathrm{R} 31=\frac{4}{10.198}=0.392 \\
& \mathrm{R} 41=\frac{3}{10.198}=0.294 \\
& \mathrm{R} 51=\frac{2}{10.198}=0.196 \\
& \mathrm{R} 61=\frac{3}{10.198}=0.294 \\
& \mathrm{R} 71=\frac{5}{10.198}=0.490 \\
& \mathrm{X} 2==9,327 \sqrt{2^{2}+2^{2}+3^{2}+2^{2}+5^{2}+5^{2}+4^{2}} \\
& \mathrm{R} 12==0.214 \frac{2}{9.327} \\
& \mathrm{R} 22==0.214 \frac{2}{9.327}
\end{aligned}
$$

$$
\begin{aligned}
& \mathrm{R} 32=0.327 \frac{3}{9.327} \\
& \mathrm{R} 42=0.241 \frac{2}{9.327} \\
& \mathrm{R} 52=0.536 \frac{5}{9.327}
\end{aligned}
$$

$$
\begin{aligned}
& \mathrm{R} 62=0.536 \frac{5}{9.327} \\
& \mathrm{R} 72==0.429 \frac{4}{9.327} \\
& \mathrm{X} 3==6,481 \sqrt{2^{2}+3^{2}+2^{2}+1^{2}+2^{2}+4^{2}+2^{2}} \\
& \mathrm{R} 13=0.309 \frac{2}{6.481}
\end{aligned}
$$$$
\mathrm{R} 23==0.463 \frac{3}{6.481}
$$

$\mathrm{R} 33=0.309 \frac{2}{6.481}$

$$
\mathrm{R} 43=0.154 \frac{1}{6.481}
$$$$
\mathrm{R} 53=0.309 \frac{2}{6.481}
$$$$
\mathrm{R} 63=0.617 \frac{4}{6.481}
$$$$
\mathrm{R} 73=0.309 \frac{2}{6.481}
$$$$
\mathrm{X} 4==7.211 \sqrt{4^{2}+4^{2}+2^{2}+2^{2}+2^{2}+2^{2}+2^{2}}
$$

$\mathrm{R} 14=0.557 \frac{4}{7.211}$

$\mathrm{R} 24=0.557 \frac{4}{7.211}$

$\mathrm{R} 34=0.277 \frac{2}{7.211}$

$\mathrm{R} 44=0.277 \frac{2}{7.211}$

$\mathrm{R} 54==0.277 \frac{2}{7.211}$

$\mathrm{R} 64=0.277 \frac{2}{7.211}$

$\mathrm{R} 74=0.277 \frac{2}{7.211}$

$X 5==8888 \sqrt{4^{2}+4^{2}+4^{2}+3^{2}+3^{2}+2^{2}+3^{2}}$ 


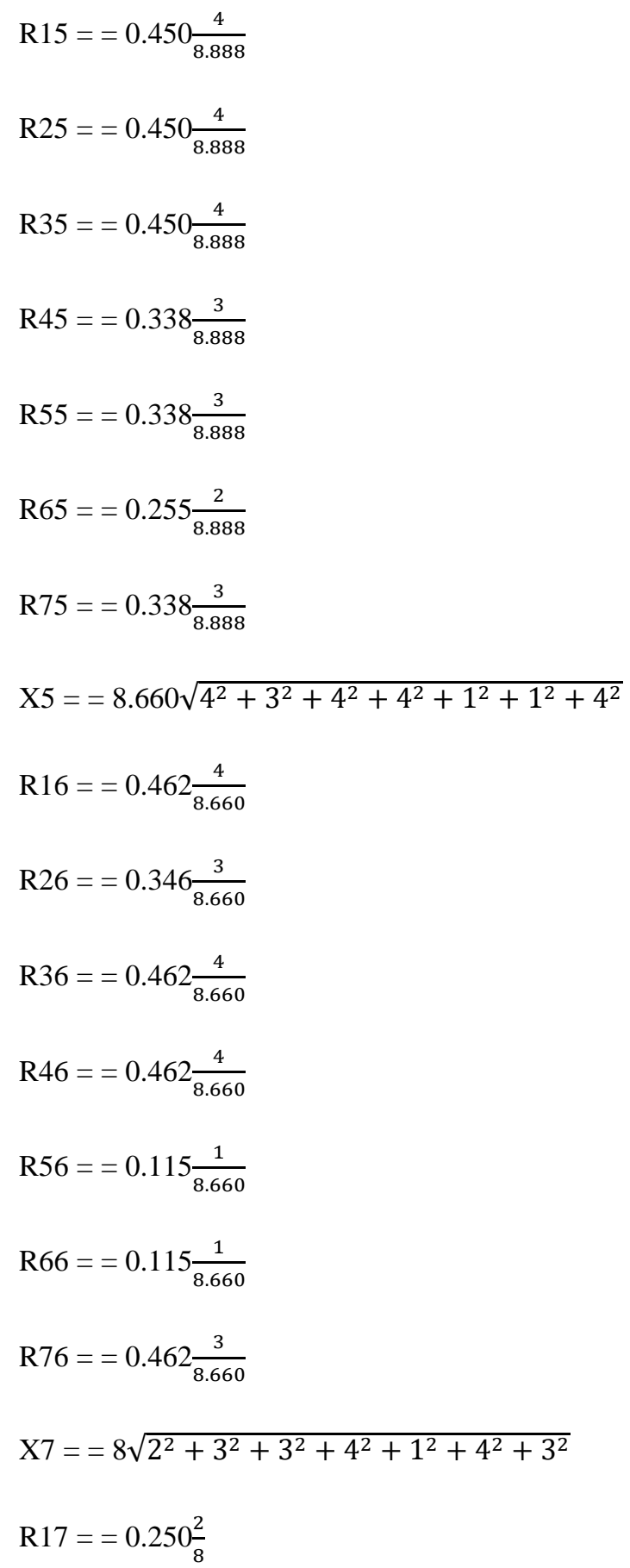

$$
\begin{aligned}
& \mathrm{R} 27=0.375 \frac{3}{8} \\
& \mathrm{R} 37=0.375 \frac{3}{8} \\
& \mathrm{R} 47=0.500 \frac{4}{8} \\
& \mathrm{R} 57=0.125 \frac{1}{8} \\
& \mathrm{R} 67=0.500 \frac{4}{8} \\
& \mathrm{R} 77=0.375 \frac{3}{8} \\
& X 8==7,874 \sqrt{3^{2}+2^{2}+4^{2}+4^{2}+3^{2}+2^{2}+2^{2}} \\
& \mathrm{R} 18=0.381 \frac{3}{7.874} \\
& \mathrm{R} 28==0.254 \frac{2}{7.874} \\
& \mathrm{R} 38=0.508 \frac{4}{7.874} \\
& \mathrm{R} 48=0.508 \frac{4}{7.874} \\
& \mathrm{R} 58=0.381 \frac{3}{7.874} \\
& \mathrm{R} 68=0.254 \frac{2}{7.874} \\
& \mathrm{R} 78=0.254 \frac{2}{7.874}
\end{aligned}
$$

The following is the normalized decision matrix result. The results can be seen in table 12.

\section{Table 12. Normalized Value}

$\begin{array}{llllllll}\text { C1 } & \text { C2 } & \text { C3 } & \text { C4 } & \text { C5 } & \text { C6 } & \text { C7 } & \text { C8 } \\ 0.392 & 0.214 & 0.309 & 0.555 & 0.450 & 0.462 & 0.250 & 0.381 \\ 0.490 & 0.214 & 0.463 & 0.555 & 0.450 & 0.346 & 0.375 & 0.254 \\ 0.392 & 0.322 & 0.309 & 0.277 & 0.450 & 0.462 & 0.375 & 0.508 \\ 0.294 & 0.214 & 0.154 & 0.277 & 0.338 & 0.462 & 0.500 & 0.508 \\ 0.196 & 0.536 & 0.309 & 0.277 & 0.338 & 0.115 & 0.125 & 0.381 \\ 0.294 & 0.536 & 0.617 & 0.277 & 0.225 & 0.115 & 0.500 & 0.254 \\ 0.490 & 0.429 & 0.309 & 0.277 & 0.338 & 0.462 & 0.375 & 0.254\end{array}$


1. The next step is to determine a weighted normalized matrix. In this study the weight values used are in table 10.To get the values in table 14, it will be calculated using, Formula : $y_{i j}=, w_{i} r_{i j}$

Table 13. Weighting of Each Criterion

\begin{tabular}{|c|c|c|c|c|c|c|c|c|}
\hline C1 & $\mathrm{C2}$ & $\mathrm{C3}$ & $\mathrm{C4}$ & C5 & C6 & C7 & C8 & C7 \\
\hline $0.392 \times 15 \%$ & $0.214 \times 15 \%$ & $0.309 \times 20$ & $0.555 \times 15 \%$ & $0.450 \times 15 \%$ & $0.462 \times 5 \%$ & $0.250 \times 5 \%$ & $0.381 \times 10 \%$ & $0.250 \times 5 \%$ \\
\hline $0.490 \times 15 \%$ & $0.214 \times 15 \%$ & $0.463 \times 20$ & $0.555 \times 15 \%$ & $0.450 \times 15 \%$ & $0.346 \times 5 \%$ & $0.375 \times 5 \%$ & $0.254 \times 10 \%$ & $0.375 \times 5 \%$ \\
\hline $0.392 \times 15 \%$ & $0.322 \times 15 \%$ & $0.309 \times 20$ & $0.277 \times 15 \%$ & $0.450 \times 15 \%$ & $0.462 \times 5 \%$ & $0.375 \times 5 \%$ & $0.508 \times 10 \%$ & $0.375 \times 5 \%$ \\
\hline $0.196 \times 15 \%$ & $0.536 \times 15 \%$ & $0.309 \times 20$ & $0.277 \times 15 \%$ & $0.338 \times 15 \%$ & $0.115 \times 5 \%$ & $0.125 \times 5 \%$ & $0.381 \times 10 \%$ & $0.125 \times 5 \%$ \\
\hline $0.294 \times 15 \%$ & $0.536 \times 15 \%$ & $0.617 \times 20$ & $0.277 \times 15 \%$ & $0.225 \times 15 \%$ & $0.115 \times 5 \%$ & $0.500 \times 5 \%$ & $0.254 \times 10 \%$ & $0.500 \times 5 \%$ \\
\hline
\end{tabular}

Following are the results of weighting for each criterion from the calculation of formula (2)

Table 14. Weighting of Each Criterion

\begin{tabular}{cccccccc}
\hline C1 & C2 & C3 & C4 & C5 & C6 & C7 & C8 \\
\hline $\mathbf{0 . 0 5 8 8}$ & 0.032163 & 0.061721 & 0.083205 & 0.067505 & 0.023094 & 0.0125 & 0.0381 \\
\hline $\mathbf{0 . 0 7 3 5}$ & 0.032163 & 0.092582 & 0.083205 & 0.067505 & 0.017321 & 0.01875 & 0.0254 \\
\hline $\mathbf{0 . 0 5 8 8}$ & 0.048245 & 0.061721 & 0.041603 & 0.067505 & 0.023094 & 0.01875 & 0.0508 \\
\hline $\mathbf{0 . 0 4 4 1}$ & 0.032163 & 0.030861 & 0.041603 & 0.050629 & 0.023094 & 0.025 & 0.0508 \\
\hline $\mathbf{0 . 0 2 9 4}$ & 0.080408 & 0.061721 & 0.041603 & 0.050629 & 0.005774 & 0.00625 & 0.0381 \\
\hline $\mathbf{0 . 0 4 4 1}$ & 0.080408 & 0.123443 & 0.041603 & 0.033753 & 0.005774 & 0.025 & 0.0254 \\
\hline $\mathbf{0 . 0 7 3 5}$ & 0.064327 & 0.061721 & 0.041603 & 0.050629 & 0.023094 & 0.01875 & 0.0254 \\
\hline
\end{tabular}

2. Determine the positive ideal solution matrix ( $\mathrm{y} \max$ ) and the ideal ideal solution matrix negative (y min).

The first step is to find a positive ideal solution matrix (y max), the results of which are in table 14, using formula 3.

Formula :

$\mathrm{A}^{+}=\mathrm{Y}_{1}^{+}, \mathrm{Y}_{2}^{+}, \ldots, \mathrm{Y}_{\mathrm{N}}^{+}$

The second step is to find a negative ideal solution matrix (y min), the results of which are in Table 14, using formula 4.

$\mathrm{A}^{-}=\mathrm{Y}_{1}^{-}, \mathrm{Y}_{2}^{-}, \ldots, \mathrm{Y}_{\mathrm{N}}^{-}$

Following are the results of the positive and

\begin{tabular}{ll}
\hline $\mathbf{0 . 1 2 3 4}$ & 0.0309 \\
\hline $\mathbf{0 . 0 8 3 2}$ & 0.0416 \\
\hline $\mathbf{0 . 0 6 7 5}$ & 0.0338 \\
\hline $\mathbf{0 . 0 2 3 1}$ & 0.0058 \\
\hline $\mathbf{0 . 0 2 5}$ & 0.0063 \\
\hline $\mathbf{0 . 0 5 0 8}$ & 0.0254 \\
\hline
\end{tabular}
negative ideal solution matrices shown in Table 14.

Table 14. Matrix of Positive and Negative

\begin{tabular}{lr}
\multicolumn{2}{c}{ Ideal Solutions } \\
\hline $\mathbf{A}+$ & $\mathbf{A -}$ \\
\hline $\mathbf{0 . 0 7 3 5}$ & 0.0294 \\
\hline $\mathbf{0 . 0 8 0 4}$ & 0.0322 \\
\hline
\end{tabular}


3. Calculating the alternative distance matrix with the ideal positive and negative ideal solutions. The first step,To calculate the value of each alternative with a positive ideal solution matrix using the formula 5 .

$$
D_{-}^{+}=\sqrt{\sum_{i=1}^{n}\left(Y_{-}^{+}-y_{i j}\right)^{2}}
$$

The distance between the value of each alternative and the positive ideal solution matrix is calculated:

D1 +

$$
\sqrt{(0.0735-0.0588)^{2}+(0.0804-0.03216)^{2}+} \begin{gathered}
(0.123-0.0617)^{2}+(0.083-0.083)^{2}+ \\
(0.0675-0.0675)+(0.023-0.0231)^{2}+ \\
(0.025-0.0125)^{2}+(0.508-0.381)^{2}
\end{gathered}
$$$$
=0.081676168
$$

D2 +

$$
\begin{aligned}
& \sqrt{(0.0735-0.0735)^{2}+(0.0804-0.03216)^{2}+} \begin{array}{c}
(0.123-0.0925)^{2}+(0.083-0.0832)^{2}+ \\
(0.0675-0.0675)^{2}+(0.023-0.0173)^{2}+ \\
(0.025-0.01875)^{2}+(0.508-0.0254)^{2}
\end{array} \\
= & 0.063225978
\end{aligned}
$$

D3+

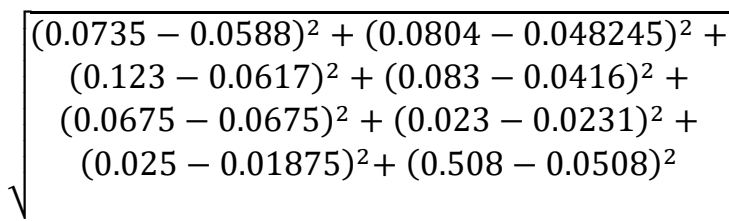

$=0.08264493$

D4 +

$$
\begin{aligned}
& (0.0735-0.0441)^{2}+(0.0804-03216)^{2}+ \\
& (0.123-0.03086)^{2}+(0.083-0.0416)^{2}+ \\
& (0.0675-0.0506)^{2}+(0.023-0.0231)^{2}+ \\
& (0.025-0.025)^{2}+(0.508-0.0508)^{2} \\
& =0.117388154
\end{aligned}
$$

D5 +

$$
\begin{aligned}
& \overline{(0.0735-0.0294)^{2}+(0.0804-0.080)^{2}+} \\
& (0.123-0.0617)^{2}+(0.083-0.0416)^{2}+ \\
& (0.0675-0.0506)^{2}+(0.023-0.0057)^{2}+ \\
& (0.025-0.00625)^{2}+(0.508-0.0381)^{2}
\end{aligned}
$$

D6 +

$$
\begin{aligned}
& (0.0735-0.0735)^{2}+(0.0804-0.0804)^{2}+ \\
& (0.123-0.1234)^{2}+(0.083-0.0416)^{2}+ \\
& (0.0675-0.0337)^{2}+(0.023-0.0057)^{2}+ \\
& (0.025-0.025)^{2}+(0.508-0.0254)^{2}
\end{aligned}
$$

$=0.068414586$

D7 +

$$
\begin{aligned}
& (0.0735-0.0441)^{2}+(0.0804-0.064)^{2}+ \\
& (0.123-0.0617)^{2}+(0.083-0.0416)^{2}+ \\
& (0.0675-0.0506)^{2}+(0.023-0.02309)^{2}+ \\
& (0.025-0.0187)^{2}+(0.508-0.0254)^{2} \\
& =0.082267537
\end{aligned}
$$

The first step, To calculate the value of each alternative with a negative ideal solution matrix using the formula 6 .

$$
D_{-}^{-}=\sqrt{\sum_{i=1}^{n}\left(\mathrm{Y}_{\mathrm{ij}}-\mathrm{y}^{-}\right)^{2}},
$$

(6)

The distance between the value of each alternative and the negative ideal solution matrix is calculated:

D1-

$$
\begin{aligned}
& \sqrt{\sqrt{(0.0588-0.0294)^{2}+(0.032163-0.0322)^{2}+}} \begin{array}{c}
(0.0617-0.0309)^{2}+(0.083-0.0416)^{2}+ \\
(0.0675-0.0338)^{2}+(0.023-0.0058)^{2}+ \\
(0.0125-0.0063)^{2}+(0.038-0.0254)^{2}
\end{array} \\
& =0.072029
\end{aligned}
$$

D2-

$$
\begin{aligned}
& \sqrt{\begin{array}{c}
(0.0735-0.0294)^{2}+(0.0321-0.0322)^{2}+ \\
(0.09258-0.0309)^{2}+(0.0832-0.0416)^{2}+ \\
(0.0675-0.0338)^{2}+(0.0173-0.0058)^{2} \\
+(0.0187-0.0063)^{2}+(0.0254-0.0254)^{2}
\end{array}} \\
= & 0.094426
\end{aligned}
$$


D3-

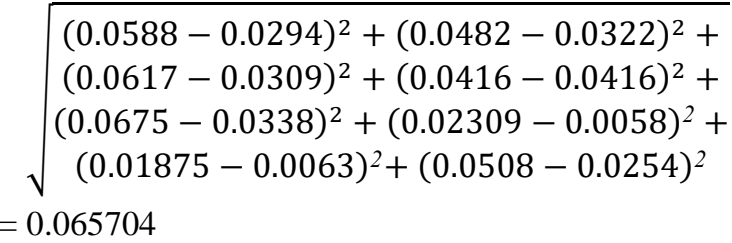

D4-

$$
\begin{aligned}
& (0.0441-0.0294)^{2}+(0.03216-0.0322)^{2}+ \\
& (0.0308-0.0309)^{2}+(0.0416-0.0416)^{2}+ \\
& (0.0506-0.0338)^{2}+(0.02309-0.0058)^{2}+ \\
& (0.025-0.0063)^{2}+(0.0508-0.0254)^{2}
\end{aligned}
$$$$
=0.042401
$$

D5-

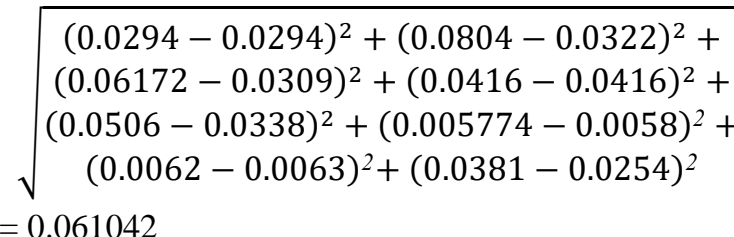

D6-

$$
\begin{aligned}
& (0.0441-0.0294)^{2}+(0.0804-0.0322)^{2}+ \\
& (0.1234-0.0309)^{2}+(0.0416-0.0416)^{2}+ \\
& (0.03375-0.0338)^{2}+(0.00577-0.0058)^{2}+ \\
& (0.025-0.0063)^{2}+(0.0254-0.0254)^{2}
\end{aligned}
$$$$
=0.107083722
$$

D7-

$$
\begin{aligned}
& \sqrt{\begin{array}{c}
(0.0735-0.0294)^{2}+(0.064327-0.0322)^{2}+ \\
(0.0617-0.0309)^{2}+(0.0416-0.0416)^{2}+ \\
(0.050629-0.0338)^{2}+(0.02309-0.0058)^{2}+ \\
(0.01875-0.0063)^{2}+(0.0254-0.0254)^{2}
\end{array}} \\
& =0.068374258
\end{aligned}
$$

Here are the resultscalculation of alternative distance matrix for positive and negative ideal solutions, can be seen in table 15 .

Table 15. Positive and Negative Ideal Solutions

\begin{tabular}{rll}
\hline Name & Positive ideal & Ideal negative \\
& & \\
\hline Coco & 0.081676168 & 0.072028662 \\
\hline Rani & 0.063225978 & 0.094425803 \\
\hline Ita & 0.08264493 & 0.065704171 \\
\hline Hana & 0.117388154 & 0.042401416 \\
\hline Irgi & 0.09265566 & 0.061041524 \\
\hline
\end{tabular}

\begin{tabular}{rll}
\hline Rian & 0.068414586 & 0.107083722 \\
\hline riza & 0.082267537 & 0.068374258 \\
\hline
\end{tabular}

4. Determine the preference value for each alternative, to calculate the preference value for each alternative, it is calculated using the formula 7 .

Formula $: D_{1}=\frac{D_{+}^{-}}{D_{\mathrm{I}}^{-}+D_{I}^{+}}(7)$

The following is the calculation of the preference value

$$
\begin{aligned}
& v_{1}=\frac{0.07202866}{0.07202866+0.081676}=1.0817 \\
& v_{2}=\frac{0.0944258}{0.0944258+0.063225978}=1.0632 \\
& v_{3}=\frac{0.065704171}{0.065704171+0.08264493}=1.0826 \\
& v_{4}=\frac{0.042401416}{0.042401416+0.117388154}=1.1174 \\
& v_{5}=\frac{0.061041524}{0.061041524+0.09265566}=1.0927 \\
& v_{6}=\frac{0.107083722}{0.107083722+0.068414586}=1.0684 \\
& v_{7}=\frac{0.068374258}{0.068374258+0.082267537}=1.0823
\end{aligned}
$$

Here are the resultscalculationpreference value for each alternative, can be seen in table 16.

Table 16. Results of Preference Value

\begin{tabular}{ll}
\hline Alternative & \multicolumn{1}{c}{ Preference Value } \\
\hline COCO & 1.0817 \\
\hline RANI & 1.0632 \\
\hline ITA & 1.0826 \\
\hline HANA & 1.1174 \\
\hline IRGI & 1.0927 \\
\hline RIAN & 1.0684 \\
\hline RIZA & 1.0823
\end{tabular}


From the calculation of the matrix above, the results are as follows:

Table 16. Analysis of Research Results

\begin{tabular}{ccc}
\hline Alternative & $\begin{array}{c}\text { Preference } \\
\text { Value }\end{array}$ & Ranking \\
\hline COCO & 1.0817 & 5 \\
\hline RANI & 1.0632 & 7 \\
\hline ITA & 1.0826 & 3 \\
\hline HANA & 1.1174 & 1 \\
\hline IRGI & 1.0927 & 2 \\
\hline RIAN & 1.0684 & 6 \\
\hline RIZA & 1.0823 & 4 \\
\hline
\end{tabular}

From the alternative calculation, Hana code has the highest preference value has a preference value of 1.1174 with rank 1.In testing using Microsoft Excel tools, Hana still has a preference value of 1.1174 with rank 1 . Then these results are the same as the preference value calculated manually and in the test. Microssoft Excel.

\section{CONCLUSION}

Based on the results of the analysis and discussion that has been carried out on the decision support system for Paskibraka candidate selection using the Topsis Method, the following conclusions can be drawn:

1. In applying the Topsis Method in the decision support system for Paskibraka candidate selection, to calculate and provide the final results of the assessment using the Topsis standard formula which can provide accurate results in determining Paskibraka candidates.

2. In the value of preference weight and criterion weight used affects the results of Topis calculations, if the value of preference weight and criteria weight is greater then the ranking result will have a greater value.
3. The Topsis method is for calculating the final value in each alternative and the ranking is in accordance with what was tested using Microsoft Excel so that the Topsis Method can be applied for the selection of candidates for paskibraka.

\section{REFERENCES}

[1] K. Youth, AND Sports, and R. Indonesia, Minister of Youth and Sports of the Republic of Indonesia Number 0065 of 2015 concerning Heritage Flag Raising Troops. 2015, p. $1-164$.

[2] S. Lestari and W. Priyodiprodjo, "Implementation of the Fuzzy TOPSIS Method for Employee Admission Selection," vol. 5, no. 2, pg. 20-26, 2011.

[3] NG Perdana and T. Widodo, "The Giving Decision Support System Scholarships for New Students Using the TOPSIS Method, "in Semantics, 2013, 2013, vol. 2013, no. November, p. 265-272.

[4] S. Mallu and SP Decision, "Decision Support System for Determining Contract Employees to Become Permanent Employees Using the Topsis Method," JITTER, vol. I, no. 2, pg. 36-42, 2015.

[5] S. Eniyati, "Designing a Decision Support System for Scholarship Admission with the SAW (Simple Additive Weighting) Method," Din. Technol. Inf., vol. 16, no. 2, pg. 171176, 2011.

[6] AM Muhammad Muslihudin, Rita Irviani, Prayugo Khoir, "Decision Support System Level Economic Classification Of Citizens Using Fuzzy Multiple Attribute Decision Increasingly," in ICCSE, 2017, p. 175.

[7] A. Andoyo, M. Muslihudin, and NY Sari, "Making Lecturer Performance Index Assessment Model Using the Fuzzy Multi Attribute Decision 
Making (FMADM) Method (Study: PTS in Lampung Province)," in Darmajaya National Seminar Proceedings, 2017, p. 195-205.

[8] T. Noviarti, M. Muslihudin, R. Irviani, and A. Maseleno, "Optimal Dengue Endemic Region Prediction using Fuzzy Simple Additive Weighting based Algorithm," Int. J. Pure Appl. Math., vol. 118, no. 7, pg. 473-478, 2018.

[9] R. Yunitarini, "Decision Support System for Radio Broadcast Selection," J. Ilm. Mikrotek, vol. 1, no. 1, pg. 43-52, 2013.

[10] Z. Yue, "TOPSIS-based group decision-making methodology in intuitionistic fuzzy setting," Inf. Sci. (Ny)., vol. 277, 2014.

[11] SK Patil and R. Kant, "A fuzzy AHPTOPSIS framework for ranking the solutions of Knowledge Management adoption in Supply Chain to overcome its barriers," Expert Syst. Appl., vol. 41, no. 2, 2014.

[12] E. Roszkowska and T. Wachowicz, "Application of fuzzy TOPSIS to scoring the negotiation offers in illstructured negotiation problems," Eur. J. Oper. Res., vol. 242, no. 3, 2015.

[13] H. Ibn-Khedher and E. Abd-Elrahman, "CDNaaS Framework: TOPSIS as Multi-Criteria Decision Making for vCDN Migration," in Procedia Computer Science, 2017, vol. 110, p. 274-281.

[14] RA Krohling and AGC Pacheco, "ATOPSIS - An approach based on TOPSIS for ranking evolutionary algorithms," in Procedia Computer Science, 2015, vol. 55, p. 308-317.

[15] TE Erkan and BD Rouyendegh, "Curriculum Change Parameters Determined by Multi Criteria Decision Making (MCDM)," Procedia - Soc. Behav. Sci., vol. 116, no. 1987, p. 1744-1747, 2014. 